GORENSKAYA O.V. ${ }^{\bowtie}$, FILIPONENKO N.S., SHCKORBATOV Yu.G.

V.N. Karazin Kharkiv National University,

Ukraine, 61022, Kharkiv, Svobody sq., 4, e-mail:olgavg2014@gmail.com, yuriy.shckorbatov@gmail.com

凶olgavg2014@gmail.com,(096)971-83-99

\title{
THE LIFESPAN OF STARVING FLIES OF DIFFERENT DROSOPHILA MELANOGASTER STOCKS: EFFECTS OF CAFFEINE AND HE-NE LASER LIGHT
}

Aim. Analysis of the chronic effects of caffeine and laser radiation on starvation resistance in Drosophila melanogaster, in depends on the genotype. Methods. The experiments were carried out in wild type stocks of Drosophila melanogaster: Canton-S and Oregon; mutant stock ebony and stocks with mutation ebony saturated by stocks Canton-S and Oregon - ebony $y_{C-S}$ and ebony $_{\text {or }}$. Caffeine was applied in concentration of $0.5 \mathrm{mg} / \mathrm{ml}$ in the cultural medium. Flies were exposed to He-Ne laser light of wavelength 632.8 $\mathrm{nm}$ and surface power density $0.03 \mathrm{~mW} / \mathrm{cm}^{2}$ for 5 minutes. Control flies were grown under standard living conditions. Results. The lifespan during starvation dependence on a genotype $(17.62 \%$ and $19.51 \%)$, external factors $(\mathrm{h}=17.02 \%$ and $19.64 \%$ ) and on the combined factors $-\mathrm{h}=4.37 \%$ and $2.42 \%$ (for males and males, respectively) was shown. Conclusions. Almost in all experimental variants caffeine and laser light induced the extension lifespan during starvation. The simultaneous applying of both factors (caffeine+laser light) induced the maximal lifespan extension in Drosophila stocks C-S, ebony, and ebony or . Such additive effect was not observed in ebony $_{C-S}$ flies. We connect the observed effects of caffeine and laser light with hormesis effect.

Keywords: drosophila, genotype, lifespan during starvation, mutation, stress tolerance.

The ability of organisms to tolerate the adverse environmental influences and the ability for adaptation is one of the basic properties of Life. The Drosophila is the common model object in studies of the mechanisms of adaptation, in particular, in environmental genetics and genetics of ageing. The Drosophila may use signal transduction pathways to modulate stress response and lifespan, and the increase of lifespan correlates with environment stress resistance, including starvation [1]. At the same time it was shown that the caloric restricted diet reduced the lifespan of domestic flies apparently due to starvation [2]. The assessment of combined effects of two external factors: of bioactive substances (caffeine) in low concentrations and also of low level He-Ne laser light are of interest in connection with the hormesis effect. This effect explains the known effect of advanced adaptation to stress factors if adverse factors are acting on biological system in consequence, by activating the stress response mechanisms. The low or modest stress leads to an overcompensation due to process of damage recovery, but also provides protection against subsequent more strong and even life threatening influences. Namely, the hormesis is a biphasic response that is characterized by stimulation at low dose and inhibition at a high dose of external factor [3]. The investigation of this effect today is very relevant, but insufficiently studied problem. Caffeine (1,3,7-trimethylxanthine) - is the common natural substance of moderately toxic action that violates reparation processes. In high concentration caffeine has a negative effect on cell cycle progression and viability, induces oxidative stress. In $1 \mathrm{mM}$ concentration caffeine is being deleterious and in $0.05 \mathrm{mM}$ being protective; in concentration of $0.05 \mathrm{mM}$ caffeine decreases the oxidative stress in hyperoxia [4]. In our previous work were demonstrated the deleterious effects of caffeine on Drosophila; the influence of caffeine of $1 \mathrm{mg} / \mathrm{ml}$, $0.5 \mathrm{mg} / \mathrm{ml}$ and $0.25 \mathrm{mg} / \mathrm{ml}$ during seven generations of treatment on formation of Drosophila melanogaster complex of adaptive traits has been studied. It has been shown, that chronic action of caffeine is accompanied by the decrease of viability at the stages of imago and pupa, shift in the Drosophila eggs laying intensity pattern toward the early reproduction, decline of stability of genetic apparatus of oocyte to the action of mutagen and decline of chromosomes polyteny level. After the fifth generation of chronic action of caffeine in the concentration of $0.25 \mathrm{mg} / \mathrm{ml}$ the values of adaptive traits reached the control level. The depressive effect of caffeine on reduplication

\section{${ }^{\circ}$ GORENSKAYA O.V., FILIPONENKO N.S., SHCKORBATOV Yu.G.}


process in polytene chromosomes has been observed during three generations [5].

The other external factor investigated as a possible hormesis-inducing factor was the $\mathrm{He}-\mathrm{Ne}$ laser light radiation. The radiation of helium-neon laser have a great impact on cell, among other effects the changes of cell proliferation and gene expression [6]. The stimulation of DNA synthesis after low-energy laser light irradiation was also shown [7].

The aim of this study was to investigate the Drosophila lifespan and the tolerance to starvation of adult Drosophila flies after chronic caffeine treatment of larvae and He-Ne laser light treatment of flies, in dependence on the genotypic peculiarities of Drosophila stocks.

\section{Materials and methods}

Drosophila stocks and laser light exposure

We used Drosophila melanogaster wild type stocks Canton-Special (C-S) (FBsn0000274) and Oregon- $R-C$ (Or) (FBst0000005), mutant stock ebony [11] (e) (FBst0000497) and stocks with mutation ebony saturated by stocks Canton-S and Oregon - ebony ${ }_{C-S}$ and ebony or . For obtaining of stocks ebony with changed genetic background (ebony $_{C-S}$ and ebony ${ }_{O r}$ ), the stock ebony was saturated by reciprocal cross with Canton-Sand Oregonin conditions of selection for ebony mutation. All stocks were obtained from Collection of Drosophila stocks of the Department of Genetics \& Cytology of V. N. Karazin Kharkiv National University (Ukraine).

All stocks were cultivated in standard $250 \mathrm{ml}$ (25 $\mathrm{mm}$ diameter) glass vials in sugar-yeast medium in incubator at temperature of $23 \pm 0.5^{\circ} \mathrm{C}$. Sorting of Drosophila adults by sex (males/females) was done during the first day after the release of puparium. Only virgin flies were selected in experiment. The ether narcotization of Drosophila was used. In experiments with caffeine it was added in culture medium in concentration of $0.5 \mathrm{mg} / \mathrm{ml}$. In experiments with laser light treatment the virgin flies were exposed to helium-neon laser light of wavelength $632.8 \mathrm{~nm}$ and surface power density $0.03 \mathrm{~mW} / \mathrm{cm}^{2}$ for 5 minutes. Control flies were grown in standard conditions. Three variants of experiments were done: flies were exposed to caffeine only, to laser light after the development of larvae in the nutrition medium with caffeine and after the development of Drosophila in standard conditions. In each vial were put 10-15 females/males. Every experiment was done in no less than 10 repeats. The number of flies of both sexes taken in our experiments was approximately 3,000 .

Lifespan determination.

Lifespan of flies in the state of starvation was determined by placing flies in test-tubes (10-15 flies in one test tube)without food, separately males and females. Plugs of cotton wool, which closes the tube, were moistened with a small amount of distilled water to prevent dehydration of flies. Counting of survivors was conducted every 3 hours up to the complete death of flies in each test tube. The lifespan of each fly in all tubes was calculated. The results were analyzed by statistical methods. To perform the statistical analysis was used the program "Biostat 2009" (AnalystSoft, USA). The mean lifespan and standard error of mean were calculated. Statistical significance of differences was determined by using two-sided Student t-test (at $\mathrm{p}<0.05$ ). Statistical significance and power of influence of factors were assessed using the twofactor analysis of variance (Snedecor method).

\section{Results and discussion}

The results of the study of Drosophila wildtype and mutant stocks lifespan under starvation in dependence of the effects of caffeine and laser light irradiation are shown in Figures 1 and 2. In Fig. 1 are presented data on lifespan of females and in the Fig. 2 - data on lifespan of males.

As one can see in Figures 1 and 2, the sexual dimorphism in lifespan of Drosophila in control is not shown. The most long-living in condition of starvation were males and females of wild type stock $C$-S. The maximum and minimum values of lifespan during starvation in control were observed for females: $123.8 \pm 4.7 \mathrm{~h}$ (stock $C-S$ ) and $94.5 \pm 2.1 \mathrm{~h}$ (stock ebony); and for males: $129.5 \pm 2.6 \mathrm{~h}$ (stock $C-S$ ) and $94.4 \pm 2.6 \mathrm{~h}$ (stock ebony $y_{O}$ ). If caffeine is added to the nutrition medium of larvae, the minimum lifespan is observed in females and males of the stock ebonyor and mutant stock ebony. Caffeine addition to cultural medium increased the average lifespan on $20.35 \%$ (females) and $16.17 \%$ (males) in comparison with control. Caffeine addition induced prolongation of lifespan in all used stocks, except females of mutant stock ebony $_{O}$, and males of mutant stock ebony.

Exposure of flies to laser light also increases longevity of females (minimally on $11.9 \%$ in stock ebony $_{\text {or }}$ and maximally on $32.8 \%$ in stock ebony), and males (on $7.3 \%$ in the stock $C-S$ and on $31.2 \%$ in stock ebony $\left.y_{C-S}\right)$. 


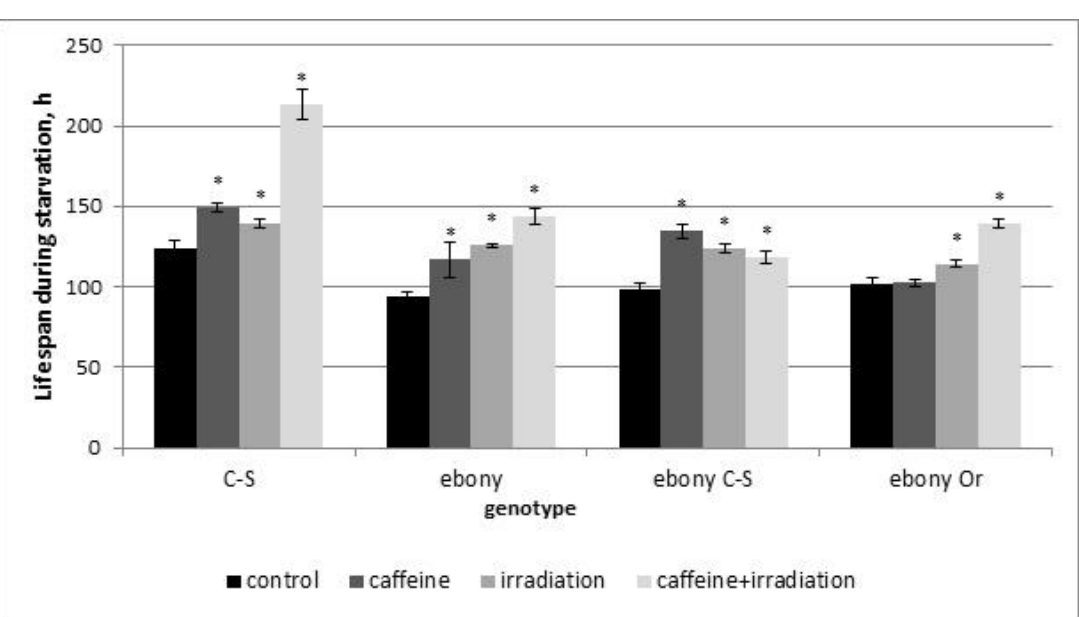

Fig. 1. Changes in lifespan of starving female Drosophila flies depending on the caffeine application, laser light irradiation, and Drosophila genotype: * probability of difference from control $\mathrm{p}<0.05$.

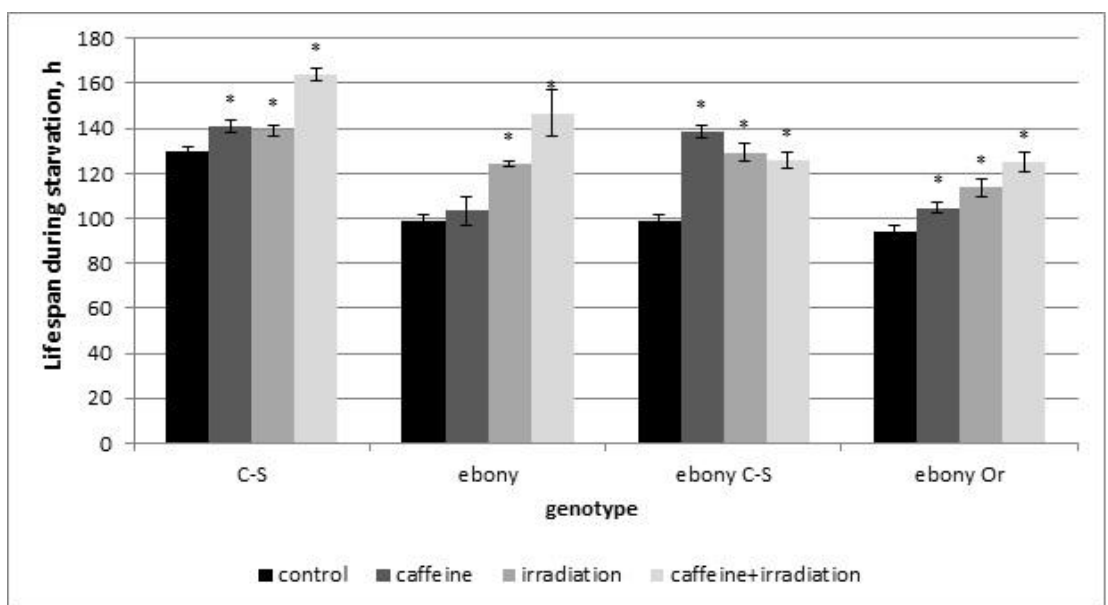

Fig. 2. Changes in lifespan of starving male Drosophila flies depending on the caffeine application, laser light irradiation, and Drosophila genotype: * probability of difference from control $\mathrm{p}<0.05$.

The simultaneous effect of caffeine and laser irradiation increased the lifespan, and the increase was more pronounced than in the cases of application of the both studied factors separately. In stock $C$-S the lifespan of females increased by $72.5 \%$ as compared with control values. The most susceptible to starvation were females and males of mutant stock ebony ${ }_{C-S}$, where the extension of lifespan was $20.1 \%$ and $27.6 \%$ (respectively, for females and males). Therefore, we demonstrated extension of lifespan of flies of both sexes of all genotypes after flies' exposure to laser light; almost in all variants (with 2 exemptions of 8 cases) caffeine induced the extension of lifespan too. The simultaneous applying of both factors induced the maximal lifespan extension in Drosophila stocks $C$ $S$, ebony, and ebony ${ }_{O r}$, therefore the additive effect of both factors was observed. Such additive effect

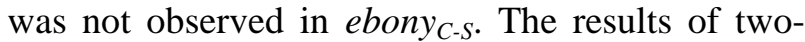
factor ANOVA analysis of the contribution of genotype and external physical and chemical factors on lifespan are shown in Table 1.

Table 1. Assessment of power of influence of external factors and genotype on lifespan of Drosophila flies

\begin{tabular}{|c|c|c|c|c|c|c|}
\hline \multirow{2}{*}{ Sex } & \multicolumn{5}{|c|}{ Factor } \\
\cline { 2 - 7 } & \multicolumn{2}{|c|}{ External factors } & \multicolumn{2}{c|}{ Genotype } & \multicolumn{2}{c|}{ External factors + genotype } \\
\hline$q$ & $\mathrm{~F}=93,57$ & $17,02 \%$ & $\mathrm{~F}=90,32$ & $17,62 \%$ & $\mathrm{~F}=6,69$ & $4,37 \%$ \\
\hline$\hat{0}$ & $\mathrm{~F}=102,11$ & $19,64 \%$ & $\mathrm{~F}=97,65$ & $19,51 \%$ & $\mathrm{~F}=3,06$ & $2,42 \%$ \\
\hline
\end{tabular}


As it may be seen from data of Table 1, the genotype and external factors significantly influence on lifespan and have approximately equal effect on it; the interaction of genetic and external factors is insignificant.

The lifespan of Drosophila in the state of starvation was investigated earlier. It should be noted that under desiccating conditions, females survived longer than males, except at low temperatures $\left(11-14^{\circ} \mathrm{C}\right)$, where males survived longer. In the presence of water, starved males always survived longer than starved females [8]. In our experiments was not observed any significant differences between lifespan of starving males and females of Drosophila. Probably it may be attributed to the genetic differences between the stocks of Drosophila used in the work [8], and in the present investigation. It is known that the survival under starvation of Drosophila melanogaster depends on the amount of carbohydrates and fats in Drosophila tissues [9]. The transcriptional response to starvation stress involved approximately $25 \%$ of the genome [10]. Starvation affects the 'de novo' synthesis of IMP (inosine monophosphate), amino acid biosynthetic processes (including L-serine biosynthesis and metabolism), lipids metabolic processes, and determinates lifespan of adult flies. In Drosophila the gene activity response to $16 \mathrm{~h}$ of starvation involved 125 up and down-regulated genes, 75 of them are specific for starvation stress and others are shared with response to $\gamma$-radiation induced stress, the stress induced by entomopathogenic fungi, and cool stress [11]. The most pronounced effects of Drosophila gene overexpression occurred in genes Hus1, mnk, mei-9, mus210, spn-B, and WRNexo, which control the processes of DNA damage recognition and repair. Lifespan and stress resistance are interrelated, more so in males than females, in that increased lifespan was associated with increased resistance to hyperthermia and oxidative stress, while decreased lifespan was associated with decreased resistance to all stressors tested in the work [12]. The role of insulin-like genes in stress resistance and longevity attracts attention of researchers. The genes encoding Drosophila insulin-like peptides (DILPs) provides potential mechanisms in modulating insulin/insulinlike signaling (IIS) events in Drosophila involved in aging and also in responses to dietary restriction answer [13]. The ablation of Drosophila insulinlike peptide-producing median neurosecretory cells
(mNSC) in the brain leads to increased glucose levels in the hemolymph of adults similar to that found in diabetic mammals. They also exhibit increased storage of lipid and carbohydrate, reduced fecundity, and reduced tolerance of heat and cold. However, the mNSC ablated flies show an extension of median and maximal lifespan and increased resistance to oxidative stress and starvation [14].

We suppose that the extension of Drosophila lifespan may be connected to hormesis effect. The negative effect of such a powerful agent, as starvation, may be attenuated by caffeine application and laser light irradiation because the applied agents are harmful at a high intensity and at a low intensity induce gene regulation effects $[8$, $15]$.

In our opinion, the known facts of interrelation of molecular events involved in the processes of aging and stress response of cells, partly mentioned above, provide a basis for understanding the molecular mechanisms of hormesis effect, shown in this article. The additional stimulation of genes shared in stress reaction to starvation and in Drosophila response to caffeine and/or to He-Ne laser light irradiation may be useful to organism and thus result in lifespan extension.

The effects of lifespan extension observed in our experiments may be connected with the involvement of free radicals modulated mechanisms. The starving leads to increase of free radical content which is one of the deleterious consequences of starvation. The D. melanogaster stocks selected for late-life reproduction and extended longevity indicate elevated oxidative stress resistance [16]. The molecular basis for oxidative stress resistance and starvation resistance is established in [17]. The caffeine as an antioxidant and a free radical scavenger [18] may reduce content of free radicals and in this way to decrease the negative effect of starvation and to increase lifespan. Laser light of low intensity was reported to produce a shift in overall cell redox potential in the direction of greater oxidation and increased ROS generation and cell redox activity [19]. The increase under laser light influence of ROS may play a "training" role inducing the increase of antioxidant enzymatic activity in Drosophila cells, and due to this process the Drosophila cells are prepared to overcome ROS increase during starvation at further stages of experiment. 


\section{Conclusions}

Summing up, the results of this work indicate the possibility to extend the lifespan of Drosophila in the state of starvation by two factors - caffeine addition to the cultural medium, and exposure of flies to laser light. In three of four tested Drosophila stocks the effect of both factors was additive. We connect the observed effects with hormesis effect and the summation of caffeine and laser light effects in our experimental model (aging/resistance to starvation).

This work was supported by the Ministry of Education and Science of Ukraine (Project State registration number: 0112U008334).

\section{References}

1. Lin Y.J., Seroude L., Benzer S. Extended life-span and stress resistance in the Drosophila mutant methuselah. Science. 1998. Vol. 282 (5390). P. 943-946.

2. Cooper T.M., Mockett R.J., Sohal B.H., Sohal R.S., Orr W.C. Effect of caloric restriction on life span of the housefly, Musca domestica. The FASEB journal. 2004. Vol. 18. P. 1591-1593. doi: 10.1096/fj.03-1464fje.

3. Calabrese E.J., Dhawan G., Kapoor R., Iavicoli I., Calabrese V. What is hormesis and its relevance to healthy aging and longevity? Biogerontology. 2015. Vol. 16 (6). P. 693-707. doi: 10.1007/s10522-015-9601-0.

4. Tiwari K.K., Chu C., Couroucli X., Moorthy B., Lingappan K. Differential concentration-specific effects of caffeine on cell viability, oxidative stress, and cell cycle in pulmonary oxygen toxicity in vitro. Biochemical and biophysical research communications. 2014. Vol. 450 (4). P. 1345-1350. doi: 10.1016/j.bbrc.2014.06.132.

5. Gorenskaya O.V. Formation of the adaptability of Drosophila melanogaster at the chronic action of caffeine The Journal of V.N. Karazin Kharkiv National University. Series: biology. 2010. Vol. 11 (905). P. 66-77.

6. Sassoli C., Chellini F., Squecco R., Tani A., Idrizaj E., Nosi D. Low intensity $635 \mathrm{~nm}$ diode laser irradiation inhibits fibroblastmyofibroblast transition reducing TRPC1 channel expression/activity: New perspectives for tissue fibrosis treatment. Lasers Surg Med. 2015. Vol. 48 (3). P. 318-332. doi: 10.1002/lsm.22441.

7. Tominaga R. Effects of He-Ne laser irradiation on fibroblasts derived from scar tissue of rat palatal mucosa. Kokubyo Gakkai Zasshi. 1990. Vol. 57 (4). P. 580-594.

8. Da Lage J-L., Capy P., David J-R. Starvation and desiccation tolerance in Drosophila melanogaster adults: Effects of environmental temperature. Journal of Insect Physiology. 1989. Vol. 35 (6). P. 453-457.

9. Marron M.T., Markow T.A., Kain K.J., Gibbs A.G. Effects of starvation and desiccation on energy metabolism in desert and mesic Drosophila. J. Insect Physiol. 2003. Vol. 49 (3). P. 261-270.

10. Harbison S.T., Chang S., Kamdar K.P., Mackay T.F. Quantitative genomics of starvation stress resistance in Drosophila. Genome Biol. 2005. Vol. 6 (4). R36.

11. Moskalev A., Zhikrivetskaya S., Krasnov G., Shaposhnikov M., Proshkina E., Borisoglebsky D. A comparison of the transcriptome of Drosophila melanogaster in response to entomopathogenic fungus, ionizing radiation, starvation and cold shock. BMC Genomics. 2015. Vol. 16 (13). S8. doi: 10.1186/1471-2164-16-S13-S8

12. Shaposhnikov M., Proshkina E., Shilova L., Zhavoronkov A., Moskalev A. Lifespan and stress resistance in drosophila with overexpressed DNA repair genes. Scientific Reports. 2015. Vol. 5. P. 15299. doi: 10.1038/srep15299

13. Kannan K., Fridell Y.W. Functional implications of Drosophila insulin-like peptides in metabolism, aging, and dietary restriction. Front Physiol. 2013. Vol. 16 (4). P. 288. doi: 10.3389/fphys.2013.00288.

14. Broughton S.J., Piper M.D.W., Ikeya T., Bass T.M., Jacobson J., Driege Y. Longer lifespan, altered metabolism, and stress resistance in Drosophila from ablation of cells making insulin-like ligands. PNAS. 2005. Vol. 102 (8). P. 3105-3110.

15. Karu T., Pyatibrat L. Gene expression under laser and light-emitting diodes radiation for modulation of cell adhesion: Possible applications for biotechnology. IUBMB Life. 2011. Vol. 63 (9). P. 747-753.

16. Harshman L. G., Haberer B.A. Oxidative stress resistance: a robust correlated response to selection in extended longevity lines of Drosophila melanogaster? J Gerontol A Biol Sci Med Sci. 2000. Vol. 55 (9). P. 415-417.

17. Tettweiler G., Miron M., Jenkins M., Sonenberg N., Lasko P. F. Starvation and oxidative stress resistance in Drosophila are mediated through the eIF4E-binding protein, d4E-BP. Genes Dev. 2005. Vol. 19 (16). P. 1840-1843.

18. Shi X., Dalal N.S., Jain A.C. Antioxidant behavior of caffeine: efficient scavenging of hydroxyl radicals. Food Chem Toxicol. 1991. Vol. 29 (1). P. 1-6.

19. Farivar S., Malekshahabi T., Shiari R. Biological effects of low level laser therapy. J Lasers Med Sci. 2014. Vol. 5 (2). P. $58-$ 62.

\section{ГОРЕНСЬКА О.В., ФІЛІПОНЕНКО Н.С., ШКОРБАТОВ Ю.Г.}

Харківський національний університет імені В.Н. Каразіна,

Украӥна, 61077, м. Харків, майдан Свободи, 4, e-mail: olgavg2014@gmail.com, yuriy.shckorbatov@gmail.com

\section{ТРИВАЛІСТЬ ЖИТТЯ ІМАГО DROSOPHILA MELANOGASTER ПРИ ГОЛОДУВАННI: ЭФЕКТ КОФЕЇНУ ТА ОПРОМІНЕННЯ НЕ-NЕ ЛАЗЕРОМ}

Mema. Визначити стійкість імаго дрозофіли до голодування після хронічної дії кофеїну і лазерного випромінювання в залежності від генотипу. Методи. Використовувалися лінії дикого типу Canton-S і Oregon, мутантна лінія ebony та лінії дикого типу з мутацією ebony $\left(e_{C-S}\right.$ та $\left.e_{O r}\right)$. У дослідах в живильне середовище додавали кофеїн в концентрації 0,5 мг/мл. Віргінних мух опромінювали гелій-неоновим лазером (довжина хвилі 
632,8 нм, потужність 0,03 мВт/см²) в двох варіантах дослідів - після розвитку мух в середовищі 3 кофеїном і після розвитку мух в стандартних умовах. Результати. Показано залежність тривалості життя імаго при голодуванні як від генотипу (сила впливу генотипу склала 17,62 \% і 19,51\%) і від впливу досліджуваних зовнішніх факторів ( $\mathrm{h}=17,02 \%$ і $19,64 \%)$, так і від поєднаної дії генотипу і зовнішніх факторів - h=4,37 \% i $2,42 \%$ (для самиць і самців відповідно). Висновки. Одночасна дія обох факторів (кофеїн + лазерне опромінення) призводить до максимального збільшення тривалості життя при голодуванні у особин $C-S, e b o n y$ и ebony ${ }_{o r}$. Ефекти кофеїну і лазерного опромінення, які спостерігаються, ми пов'язуємо з ефектом гормезису. Ключові слова: дрозофіла, генотип, тривалість життя при голодуванні, мутація, стрес-резистентність. 